\title{
Word-Power: Reading, Writing and Traveling from Story to Story in the 'Inkheart' Novels ${ }^{1}$
}

\author{
Babette Puetz
}

Many readers of fantasy books have wished they could meet the characters or even enter the fantasy worlds of these works. This idea is played out in Cornelia Funke's 'Inkheart' trilogy, where characters move back and forth between the primary world and the secondary one which is set inside a book that is also called Inkheart. The processes and consequences of these appearances and disappearances of characters in both worlds, which - for lack of a better term - I will refer to as 'world-travel', are explored in great detail in the 'Inkheart' series. A striking example of metafiction, the work centres around the processes of reading and writing fantasy. Through a discussion of the power, reciprocity, and responsibility of the author, the reader, and the characters of the story this article will examine the author's claim that her fantasy is not escapist.

The two main worlds in Funke's work are contemporary Italy and the Inkworld of the book within the book. The Inkworld, like so many fantasy worlds, is given a pseudomedieval setting with castles, princes and strolling players (cf. Hunt and Lenz 2001, p.4.). It is filled with fairytale elements, such as fabulous creatures like giants and fire-elves, and some magic. A number of characters manage to move from one world to the other. The processes and effects of world-travel are treated in the trilogy as follows: The first volume of the series, Inkheart, deals with the effects of characters who have entered the primary world from the secondary world. In its second volume, Inkspell, characters from the primary world enter the Inkworld. They attempt to change matters there, but tend to achieve unforeseen and undesirable results. In volume three, Inkdeath, the main characters from the primary world are at the centre of a powerstruggle in the Inkworld, and it is one of them who finally manages to resolve the problem.

In order to achieve 'world-travel', a gifted reader must read aloud a special text. It ideally consists of the words originally written by the author (or sub-creator, cf. Tolkien 1964, p.36) in this case by the Inkheart-author Fenoglio. Alternatively, a text may be newly composed of no other words than those which appear in the original work describing the secondary world (Inkspell p.18). It must be read aloud by the reader in such a lively and convincing manner that the words literally come to life (Inkheart pp.182-3, Inkspell p.187). A problem is posed by the scarcity of the means and gifts required: the Inkheart-author Fenoglio is lazy and often suffers from writer's block (e.g. Inkspell p.430), the only remaining copy of Inkheart is in the possession of the very possessive and greedy Orpheus throughout much of the trilogy, and there are only four gifted readers, the bookbinder Mo, his twelve-year-old daughter Meggie, the librarian Darius, and the Inkworldenthusiast Orpheus; of these Mo and Darius are somewhat reluctant to use their powers.

The situation is further complicated by various obstacles and rules. Firstly, even gifted readers using the right words cannot always achieve exactly what they aim for. Orpheus, for instance, is both a clever author and a gifted reader, but he lacks the ability to read himself into the Inkworld (Inkspell pp.18; pp.658-9). Furthermore, some characters do not make the transition unscathed, emerging mute or disfigured (Inkheart p.175, Inkspell p.32). 
Secondly, for every creature which enters a world, another creature - neither the reader nor the author can determine which - will leave this particular world and come into the reader's world (Inkspell p.296). The consequence is that at least half of the world-travel is not voluntary and can bring both unhappiness and confusion. The characters in the 'Inkheart' books do not forget their own worlds and can be severely homesick with no easy means of return, and their absence is noticed at home.

Funke said in an interview that her fantasy is not escapism but has an effect similar to that of Brecht's Verfremdungseffekt or 'estrangement', also known as 'alienation'. 'This is an unusual view since fantasy is often regarded as escapist (as Tolkien famously complained in Tree and Leaf 1964, p.53). The present article investigates how and to what effect Funke's claim is realised in Inkheart, how the use of alternative worlds is central to its realisation, and which roles the author, the reader, and the characters of the story play in it. The discussion begins with a definition of the term 'estrangement', then looks at ways in which the theory can be applied to a children's novel in general and to the 'Inkheart' books in particular, next considers the power, mutual dependency, and responsibility of the author, the reader, and the characters of the story, and comes to a conclusion which outlines the effects of 'estrangement' in the trilogy.

The term 'estrangement' is closely connected with the German dramatist Bertolt Brecht and his theory of the epic theatre. In contrast to Aristotelian dramatic theory, he intended his audience to realise that what was presented to them on stage was not an illusion of reality but a depiction of human behaviour in a certain context. He wanted to make his audience see the action on stage in a detached manner which prevented them from identifying with the characters and actions of the play. This was to enable the spectators to reflect critically on what they were watching and by extension on society in general. Brecht defined 'estrangement' as 'a representation (...) which allows us to recognize its subject, but at the same time makes it feel unfamiliar" (Brecht (BT 192), in: Rouse 1989, p.33). In order to achieve this 'unfamiliarity', Brechtian 'estrangement' uses a variety of techniques aimed at breaking the dramatic illusion, including plots moving in leaps, unexpectedly changing characters, and characters stepping out of their roles and addressing the audience (Cf. Gray 1976, p.72, also Rouse 1989, p.34, Dickson 1978, p.234, Brooker 1994, pp.191ff.).

It is often seen as problematic to transfer a theory designed for one literary genre to another. But since in this case Funke herself has made the connection, it is worth exploring. ${ }^{3}$ Of course, only devices of 'estrangement' which do not depend on a staged performance (such as showing the sources of lighting and music on the theatre-stage) can be applied to a novel. At the same time, such characteristic elements of 'estrangement' as unexpected changes in plot or characters, cannot be found in the trilogy, nor do the 'Inkheart' books try to prevent the reader from identifying with characters. On the contrary, we are shown the strong emotions of all the main characters and can empathise with most of them. The readers within the novels, especially Meggie and Orpheus, also identify with the fictional world, which culminates in Meggie reading herself into the Inkworld. Orpheus says about Inkheart:

This book taught me, once and for all, how easily you can escape this world with the help of words! You can find friends between the pages of a book (...) Have you any idea how bitterly I wept when I read about your [i.e. Dustfinger's] death?

(Inkspell p.17)

This quotation about a fictional character's emotional involvement with the figures in a novel reflects our own reading experience of Funke's trilogy. However, at least one feature 
in the trilogy is quintessentially 'estranging': In a self-reflexive, metafictive way, these books constantly make readers reflect on their own act of reading a work of fiction by a living author, which is so gripping that readers can easily lose themselves in the story.

It is stressed in the novels that author and reader are equally important in bringing the fantasy world to life. The idea of the codependency and reciprocity of the author and the reader has already been suggested in theories of fantasy from the 1960s and 1970s (Tolkien 1964, p.36, Ingarden 1968, pp.49-55, Todrov 1973, pp.31-33 and 157, Iser 1974, pp.274-276). The author's idea needs to be realised in the mind of the reader. Funke, however, takes the idea of author-readerreciprocity a step further: in Inkheart the reader has to read a text aloud in such a lively manner that the fantasy is not just realised in the reader's mind, but literally, i.e. by live figures appearing out of a book. Furthermore, Funke shows us that this process is extremely complex when Fenoglio's and Meggie's attmepts to improve the Inkworld's current situation under the oppressive regime of the evil king Adderhead backfire, and when another author, Orpheus, makes his own changes to the Inkworld although he is not its sub-creator.

Author-reader-reciprocity is also hinted at through the epigraphs to each chapter which draw on a wide range of children's and adult literature. Here intertextuality is used as a means to emphasise the novels' strongly metafictive character: Each quotation relates to the content of the chapter, almost as if it was at least in part realised in Meggie's world. This is particularly apparent in the poem by the Holocaust survivor Paul Celan at the very beginning of the German edition of Inkheart (Funke, interestingly, has chosen to omit it in the English translation): ${ }^{4}$
Kam, kam.

Kam ein Wort, kam,

kam durch die Nacht, wollt leuchten, wollt leuchten.

Asche.

Asche, Asche.

Nacht.

Came, came.

Came a word, came

came through the night, wanted to shine, wanted to shine

Ash.

Ash, ash.

Night.

(Celan, Engfiihrung, 1980,p.119; Tintenherzp.7)

The themes 'words', 'fire', 'ashes', and especially 'burning of books', run through Inkheart. In particular, the criminal Capricorn is attempting to burn all the existing copies of Inkheart so that no one can read him back into the secondary world, and Meggie's great-aunt Elinor's enormous library is burned down by Capricorn's men who threaten their opponents through arson (Inkheart pp.169-171, 287-288; cf. also Inkspell pp.370-1). The Celan epigraph thus adds an extra layer of significance to the story through its reference to the Nazi regime's book burnings. The quotation reminds the readers that books have been burned in real life and so make Capricorn and his men appear even more threatening. The strong connection between reality and fantasy is further emphasised through the appearance of (the German edition of) the book Inkheart, which looks quite like the book within the book as described at Inkheart p.54. ${ }^{5}$ The idea of a blurring of the boundaries of fiction and reality is also strongly felt by the characters themselves. This already becomes clear early in the trilogy, when Meggie finally gets the long awaited chance to read Inkheart but is suddenly afraid to open the book: 
For the very first time in her life Meggie wasn't sure that she wanted to enter the world waiting for her between the covers of a book. All the bad things that had happened over the last three days seemed to have come out of this book, and perhaps they were only a faint reflection of what still awaited her inside it.

(Inkheart p.98)

Meggie's instincts turn out to be correct: the boundaries between the reality of the primary text and the fiction of the secondary world are completely obscured.

The idea that fiction affects reality raises the question of the responsibility of the author and the reader of fantasy. The theme of the responsibility of the reader is dealt with throughout the trilogy. We are shown the consequences of Meggie's reading, especially when she reads the troublesome Orpheus and the useless look-alike prince Cosimo into the Inkworld (Inkspell pp.296-298, 570, 658-659). The topic of the reader's responsibility is furthermore explicitly problematised by Mo who refuses Elinor's request to read nice creatures out of books for her:

Who knows who might disappear next time? And perhaps there's some unpleasant character we never noticed even in the Pooh books. Or suppose I read Pooh himself out of his book? What would he do here without his friends and the Thousand-Acre-Wood?

His poor little heart would break (...). (Inkheart p.158)

The negative results of world-travel mentioned here are both depicted in Inkheart: When Mo discovers his talent of reading characters into and out of stories, he accidentally makes his wife disappear and the evil characters Capricorn and Basta appear. At the same time Dustfinger enters the primary world and never stops suffering from extreme homesickness to the Inkworld (Inkheart pp.143-149, 151).

As to the responsibility of the author, he or she is fundamental in creating and shaping the secondary world. But does the author always change the story for the better? Not in Fenoglio's case: the old man has lost the overview of many of the details of his fictional world; and his ideas, which are supposed to improve the situation, usually do not work out quite the way he had intended: "Whenever he began to hope he was getting things under control again, something happened that did not remotely suit his plans." (Inkspell p.356) Orpheus displays an even greater lack of responsibility. He uses his knowledge of ways of changing the Inkworld to his own advantage by reading himself treasures out of the story and adjusting matters according to his personal whims - such as multi-coloured fairies - or his personal advantage, especially when he tries to ingratiate himself with king Adderhead (Tintentod pp.31, 53, 426-440). Orpheus is a special case because he combines the powers of both, author and reader, in the same person. For this reason, he poses a serious threat to all Meggie, Fenoglio, Mo and their friends are trying to achieve - until Mo intervenes by killing the Adderhead and Orpheus flees (Tintentod p.724). ${ }^{6}$

To this debate Funke has added a new, fantastical aspect: the problem of the power and responsibility of the story-characters themselves to change their world and their reciprocal relationship with the author and the reader. Apparently, the secondary world is not confined to the small part of it which the author has written about (Inkspell pp.15, 147, 440441). Mo explains: "Stories never really end, Meggie, (...) even if the books like to pretend they do. Stories always go on. They don't end on the last page, any more than they begin on the first page." (Inkspell p.59) The idea that 
characters develop lives of their own and start acting independently from the author is a common writer's claim (e.g. Mendlesohn p.183, Funke: see n. 6 below), but in this work of metafiction it also has a deeper meaning: It can be interpreted as another way to express the theory that fantasy is metaphorical (cf. Stephens p.249, Mendlesohn pp.168-169), i.e. that it is not separated from reality but reflects it. Funke plays out this theory in her story by showing how a fantasy novel not only becomes "reality" for Meggie, Mo and some other characters from the primary world, but how they also bring their own reality into the "reality" of the fantasy story. In other words, not only do the characters in the Inkworld introduce changes which Fenoglio and his readers cannot foresee and some of which have terrible consequences for the inhabitants of this world, but the visitors from the primary world leave their own mark on the secondary world. It is, moreover, in the final volume of the trilogy, not just the author of the story and a reader who change its outcome, but Mo, acting as a character, must take the initiative to kill the Adderhead. Although he possesses the special talent, Mo chooses not to act as a reader in the Inkworld, not even in his fight against the Adderhead (as opposed to the killing of Capricorn in Inkheart). He was even read into the Inkworld by someone else (Orpheus, see Inkspell p.187). He does, however, take on a literary role, that of the robber known as the Bluejay, a Robin Hood-like figure from Fenoglio's songs. Fenoglio had originally based this character on Mo, and already in Inkspell Mo was repeatedly mistaken for the robber (Inkspell p.354-355). His dual identity (as bookbinder from the primary world and robber from the secondary world) and the power of both sides of his character are vividly portrayed in an inner dialogue of Mo's two identities while he is imprisoned by the Adderhead and forced to bind him a new Book of Immortality under the supervision of one of the king's men, the Piper:
The Bluejay longed to thrust the bookbinder's knife into his [i.e. the Piper's] heartless breast, but Mo sent him away another time. What are you waiting for? asked the Bluejay. For the empty book? You will never find it! - Then why should I still fight? asked Mo in return. Without the book I am dead and so is my daughter. Meggie. Only in fearing for her, the bookbinder and the Bluejay were one.

(Tintentod pp.709-710, my translation)

Directly after this passage, when Mo writes in the Book of Immortality the three words, "heart", "blood", and "death" (Inkspell p.531), which are required to kill the Adderhead, he is tellingly referred to only as Mo, never as the Bluejay under whose name he is held captive (Tintentod pp.710-712). ${ }^{7}$ Mo is thus portrayed as a man who includes strong parts of both worlds in his one character, but it is stressed that it is the character-part from the primary world which finally succeeds in freeing the Inkworld from the Adderhead. This reinforces the notion that characters are dependent on both, an author and a reader, since both were necessary to bring the Bluejay into existence and Mo into the Inkworld. Mo kills the Adderhead by writing, but he is putting words on paper which have previously been determined in writing by the sub-creator of the Inkworld, Fenoglio, in a passage partly read out by Meggie. Early in Inkheart, Mo's occupation as a bookbinder is defined as a "book doctor" (Inkheart p.19). This implies that he preserves the written word but does not interfere with it, matching his long-lasting refusal to read aloud. Fenoglio's text had to be read out by a gifted reader so it would start happening. That Meggie did not manage to read out the whole passage about the Book of Immortality (Inkspell pp.510-512) does not matter anymore. It is the combination of the powers of all three, author, reader, and character, which causes the final, most important change to the fate of the 
Inkworld. The author's words are the basis, they are at least partly realised with the help of a reader, and finally a character executes what was initially set in motion by the author and the reader.

To conclude, Funke causes us to reflect critically on our roles as readers, and on writing and story-telling in general. Through this selfreflexive, metafictive strategy, the author makes us step back from the text and from our emotional involvement with the characters and actions. Thus, unlikely as it seems at first sight, the Inkheart trilogy indeed contains a kind of 'estrangement'. Funke's novels can be read and enjoyed without the added level of meaning brought about by 'estrangement', but they receive a wider significance through this second layer of interpretation which connects the fantasy particularly tightly with reality. This connection is also strongly emphasised through the use of the Celan quotation at the very beginning of the trilogy. One can innocently read the novels as an adventure story full of evil characters, but the quotation adds a deeper layer to it by connecting the story to, and making us reflect on, our own society. ${ }^{8}$ Whereas even in a one-dimensional reading of the trilogy, the fantasy text - to speak with Stephens p.249 reflects reality in general, the reading of the books on more than one level further strengthens this relationship of fantasy and reality by connecting the fantasy to a particular historical event (rather than reality in general). This strategy results in a total disruption of the reader's state of enchantment which gives deeper meaning to the text. This contradicts Tolkien's $(1964,36)$ well-known view that the art of fantasy fails when the reader's state of enchantment is disturbed. Funke's art, on the contrary, is actually enhanced by the breaking of the illusion: Funke blurs the boundaries of fantasy and reality with such great skill that she creates a strikingly sophisticated form of fantasy which can be read and enjoyed on two levels. In fact, that the novels can be read in these two ways is, I think, one of the main reasons why they are enjoyed by such a range of ages - by children ${ }^{9}$ and equally by adults. Funke's fantasy effectively juggles both escapist illusion through enchantment and reflective disillusion through 'estrangement'.

\section{NOTES}

1. I would like to thank Tatjana Schäfer, Harry Ricketts and the anonymous peer-reviewer for Papers for their comments on earlier versions of this article and the audience at the ACLAR conference in Wellington, N.Z. in June 2008 where I gave a paper on this topic.

2. Konrad Heidkamp, "Ich liebe es, wenn meine Leser flüstern", Die Zeit 15.09.2005 Nr. 38. http://images.zeit.de/text/2005/38/S_55_Funke, accessed on 08.01.2008. Funke is quoted as saying about her writing: "Die Welt mit den Augen anderer sehen, als etwas Fremdes, das muss Fantasy leisten. Dann ist sie keine Flucht, dann hat sie einen ähnlichen Effekt wie Brechts Verfremdungstheorie." (Seeing the world with the eyes of others, as something strange, that is what fantasy has to achieve. Then it is not escapism, then it has an effect similar to Brecht's estrangement theory.)

3. Furthermore, Inkheart is currently being filmed and the first two volumes of the trilogy have been performed on stage.

4. It is replaced by a Shel Silverstein passage about story-telling, which also fits the book but does not carry the significance for the story of the Celan quote. The publisher (emails from Elinor Bagenal from Chicken House Publishing on 16.06.2008 and 25.06.2008) tells me that Funke changed some of the epigraphs because of copyright difficulties and because some did not translate so well into English. This may imply that she thought that the Celan poem might not carry the same significance for readers in the English speaking world as it does for Germans. 
5. For the concept cf. Michael Ende's The Neverending Story p.6, when Bastian first looks at the book into which he is soon to travel and which looks like the book the reader is holding:

It was bound in copper-colored silk that shimmered when he [Bastian] moved it about. Leafing through the pages, he saw the book was printed in two colors. There seemed to be no pictures, but there were large, beautiful capital letters at the beginning of the chapters. Examining the binding more closely, he discovered two snakes on it, one light and one dark. They were biting each other's tail, so forming an oval. And inside the oval, in strangely intricate letters he saw the title: The Neverending Story.

6. The question of the power and responsibility of the author is one which Funke has spoken about in interviews. She has been reported as saying that she herself as an author never knows the endings of the stories she writes, and that her own characters often surprise her, but she also admits that the author sometimes needs to intervene and that she enjoys being the dictator in the world she is creating. See: http://www.faz.net/s/Rub1DA1FB848C1E4485 8CB87A0FE6AD1B68/Doc E834D3C022428 43B3B51BAAB8CA399FE0 ATpl Ecommon Scontent.html, accessed on 24.04.2008. This reminds one of Fenoglio's statements in Inkheart p.268: "Every writer wants to create lifelike characters - and mine are so lifelike they've walked straight off the page!" When Meggie reminds him that Mo can also read characters out of other books, he answers: "A good thing you reminded me. Otherwise I might start taking myself for a minor god, mightn't I?"

See also Nelson 2006, p.233. On the topic of the responsibility of the author see also Hiley 2006, pp.131-133.

7. When Mo is binding the Book of Immortality in Inkspell, he is also referred to as Mo, which is not surprising since he himself has at that point not identified with the Bluejay. However, both the librarian Taddeo and the Adderhead raise the issue of his identity as the Bluejay in this passage: Inkspell pp.578-585, 589, 600602, 608.

8. I strongly disagree with Gelberg 2004, p.27 who finds the Celan quote is inappropriate and hardly bearable because in his opinion Funke does not write high literature.

9. Amazon.de's age recommendation is for children from 10 years onwards:

http://www.amazon.de/Tintenherz-Tintenwelt01-Cornelia-

Funke/dp/3791504657/ref=sr_1_1?ie=UTF8\&s $=$ books\&qid $=1213406298 \& \mathrm{sr}=1-1$, accessed on 14.06.2008

\section{REFERENCES}

Brooker, P. (1994) 'Key words in Brecht's theory and practice of theatre', in $\mathrm{P}$. Thomson \& G. Sacks (eds) The Cambridge Companion to Brecht. Cambridge, Cambridge University Press. pp. 185-200.

Celan, P. (1980) Poems. A Bilingual Edition. sel., transl., intr. M. Hamburger. New York, Persea Books.

Dickson, K.A. (1978) Towards Utopia. A Study of Brecht. Oxford, Clarendon Press.

Ende, M. (1983, German original 1979) transl. R. Manheim. The Neverending Story. New York, Dutton Children's Books.

Gelberg, H.-J. (2004) “ “Tintenherz” - ein Herz voller Tinte', Eselsohr 8, 26-27.

Gray, R. (1976) Brecht the Dramatist. Cambridge, Cambridge University Press. 
Funke, C. (2003) Tintenherz. Hamburg,

Cecilie Dressler Verlag. (2003a) Inkheart. Frome, Sommerset,

The Chicken House. (2005) Tintenblut. Hamburg, Cecilie

Dressler Verlag. (2005a) Inkspell. Frome, Sommerset,

The Chicken House. (2007) Tintentod. Hamburg, Cecilie

Dressler Verlag.

Hiley, M. (2006) '(Sub)Creation and the

Written Word in Michael Ende's

Neverending Story and Cornelia Funke's

Inkheart', in J. Deszcz-Tryhubczak \& M.

Oziewicz (eds) Towards or Back to Human

Values? Spritual and Moral Dimensions of

Contemporary Fantasy. Cambridge,

Cambridge Scholars Press, pp.121-134.

Hunt, P. \& Lenz, M. (eds) (2001) Alternative

Worlds in Fantasy Fiction. London and New

York, Continuum.

Ingarden, R. (1968) Vom Erkennen des literarischen Kunstwerks. Darmstadt, Wissenschaftliche Buchgesellschaft. Iser, W. (1974) The Implied Reader. Patterns of Communication in Prose Fiction from Bunyan to Beckett. Baltimore, Johns Hopkins University Press.

Mendlesohn, F. (2005) Diana Wynne Jones: Children's Literature and the Fantastic Tradition. New York and London, Routledge.

Nelson, C. (2006) 'Writing the Reader: The Literary Child in and Beyond the Book', Children's Literature Association Quarterly 31,3, 222-236.

Rouse, J. (1989) Brecht and the West German Theater. Ann Arbor, UMI Research Press.
Stephens. J. (1992) Language and ideology in children's fiction. London and New York, Longman.

Todrov, T. (1973) The Fantastic. A Structural Approach to a Literary Genre.

Cleveland/London, The Press of Case

Western Reserve University.

Tolkien, J.R.R. (1964) 'On Fairy-Stories', in Tree and Leaf. London, George Allen and Unwin, pp.11-70.

\section{Websites}

http://images.zeit.de/text/2005/38/S_55_Funke (Konrad Heidkamp, "Ich liebe es, wenn meine Leser flüstern”, Die Zeit 15.09.2005 Nr. 38.), accessed on 08.01.2008.

http://www.faz.net/s/Rub1DA1FB848C1E4485 8CB87A0FE6AD1B68/Doc E834D3C02242 843B3B51BAAB8CA399FE0 ATpl Ecom mon Scontent.html, accessed on 24.04.2008.

http://www.amazon.de/Tintenherz-Tintenwelt01-CorneliaFunke/dp/3791504657/ref=sr_1_1?ie=UTF8

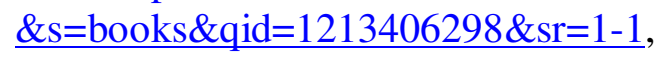
accessed on 14.06.2008.

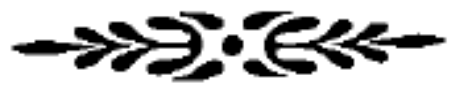

\section{BIOGRAPHICAL NOTE}

Babette Puetz teaches Drama and Myth in the Classics programme of Victoria University of Wellington. She has a special interest in Aristophanes. Babette has an MA and $\mathrm{PhD}$ from the University of St Andrews. She has taught at universities in Great Britain and the US. 